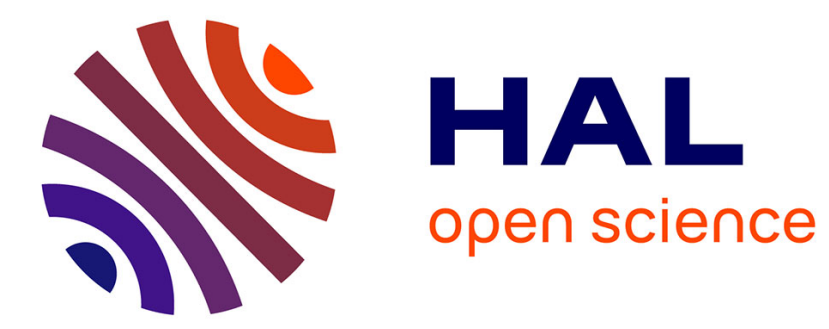

\title{
Ocean primary production derived from satellite data: An evaluation with atmospheric oxygen measurements
}

Yves Balkanski, Patrick Monfray, Mark Battle, Martin Heimann

\section{To cite this version:}

Yves Balkanski, Patrick Monfray, Mark Battle, Martin Heimann. Ocean primary production derived from satellite data: An evaluation with atmospheric oxygen measurements. Global Biogeochemical Cycles, 1999, 13 (2), pp.257 - 271. 10.1029/98GB02312 . hal-02872423

\section{HAL Id: hal-02872423 \\ https://hal.science/hal-02872423}

Submitted on 25 Jan 2021

HAL is a multi-disciplinary open access archive for the deposit and dissemination of scientific research documents, whether they are published or not. The documents may come from teaching and research institutions in France or abroad, or from public or private research centers.
L'archive ouverte pluridisciplinaire HAL, est destinée au dépôt et à la diffusion de documents scientifiques de niveau recherche, publiés ou non, émanant des établissements d'enseignement et de recherche français ou étrangers, des laboratoires publics ou privés. 


\title{
Ocean primary production derived from satellite data: An evaluation with atmospheric oxygen measurements
}

\author{
Yves Balkanski and Patrick Monfray \\ Laboratoire des Sciences du Climat et de l'Environnement, Commissariat à l'Energie Atomique, Gif-sur-Yvette, France \\ Mark Battle \\ Department of Geosciences, Princeton University, Princeton, New Jersey \\ Martin Heimann \\ M. Heimann, Max-Planck-Institut fuer Biogeochemie, Jena, Germany
}

\begin{abstract}
Recently, very precise measurements have detected the seasonal variability in the atmospheric $\mathrm{O}_{2} / \mathrm{N}_{2}$ ratio at several sites in the northern and southern hemispheres. In this paper, we derive marine primary productivity (PP) from satellite ocean color data. To infer air-sea oxygen fluxes, a simple one-dimensional diagnostic model of ocean biology has been developed that depends on only two parameters: a time delay between organic production and oxidation (set to 2 weeks) and an export scale length $(50 \mathrm{~m})$. This model gives a global net community production of $4.3 \mathrm{~mol} \mathrm{C} \mathrm{m}^{-2} \mathrm{yr}^{-1}$ in the euphotic zone and $3.2 \mathrm{~mol} \mathrm{C} \mathrm{m}^{-2} \mathrm{yr}^{-1}$ in the mixed layer. This last value corresponds to a global $f$ ratio (net community production (NCP)/PP) at the base of the mixed layer of 0.37 . The air-sea fluxes derived from this model are then used at the base of a three-dimensional atmospheric model to compare the atmospheric seasonal cycle of $\mathrm{O}_{2} / \mathrm{N}_{2}$ at five sites: Cape Grim (40.6 $\left.6^{\circ} \mathrm{S}, 144.6 \mathrm{E}\right)$, Baring Head $\left(41.3^{\circ} \mathrm{S}, 174.8^{\circ} \mathrm{E}\right)$, Mauna Loa $\left(19.5^{\circ} \mathrm{N}, 154.8^{\circ} \mathrm{W}\right)$, La Jolla $\left(32.9^{\circ} \mathrm{N}, 117.3^{\circ} \mathrm{W}\right)$, and Barrow $\left(71.3^{\circ} \mathrm{N}, 156.6^{\circ} \mathrm{W}\right)$. The agreement between model and observations is very encouraging. We infer from the agreement that the seasonal variations in $\mathrm{O}_{2} / \mathrm{N}_{2}$ are largely controlled by the photosynthesis rate but also by the remineralization linked to the deepening and shoaling of the mixed layer. Lateral ventilation to high latitudes may also be an important factor controlling the amplitude of the seasonal cycle.
\end{abstract}

\section{Introduction}

In this paper we use atmospheric oxygen measurements to assess predicted air-sea fluxes of oxygen derived from satellite ocean color. Atmospheric oxygen measurements integrate air-sea oxygen fluxes over very large oceanic expanses and are well suited to assess strengths and weaknesses of oceanic carbon models predictions of oxygen and carbon fluxes. Seasonal variations in the concentration of $\mathrm{O}_{2}$ in the atmosphere are induced by the same processes that influence carbon dioxide concentration changes. On land, these processes include photosynthesis, plant respiration, soil respiration, changes in land use, and fossil fuel combustion. In the ocean, processes causing

Copyright 1999 by the American Geophysical Union.

Paper number 98GB02312

0886-6236/99/98GB-02312\$12.00 variations of atmospheric oxygen are photosynthesis and respiration from marine biota, ventilation, and thermal invasion and evasion due to variations in gas solubility.

Although oxygen is the second most abundant constituent of the atmosphere and amounts to $20.946 \%$ of its volume [Machta and Hughes, 1970], the combined effects of the above processes induce seasonal variations in its relative abundance of up to 200 parts per million. Following the definition of Keeling and Shertz (1992) (hereinafter referred to as K-S), we express relative changes in the oxygen/nitrogen ratio of air in units of "per meg", i.e. multiply by $10^{6}$ the relative deviation from a reference

$$
\delta\left(\mathrm{O}_{2} / \mathrm{N}_{2}\right)=10^{6}\left[\left(\mathrm{O}_{2} / \mathrm{N}_{2}\right)_{\text {sample }} /\left(\mathrm{O}_{2} / \mathrm{N}_{2}\right)_{\text {reference }}-1\right]
$$

Carbon dioxide forms carbonic acid, bicarbonate, and carbonate ions in seawater and equilibrates with the atmosphere in about a year. In contrast, the equilibration time for dissolved oxygen is typically only 3 weeks 
[Broecker and Peng, 1982]. The chemical reactions of $\mathrm{CO}_{2}$ in seawater cause the ocean to be a large reservoir for carbon and a comparatively small one for oxygen [Keeling et al., 1993]. As a consequence, seasonal atmospheric variations induced by oceanic processes are much larger for $\mathrm{O}_{2}$ than for $\mathrm{CO}_{2}$. Because emissions of fossil fuel $\mathrm{CO}_{2}$ are largely aseasonal and oceanic thermal effects (discussed below) tend to be out of phase with $\mathrm{CO}_{2}$ fluxes caused by ocean biology, almost the entire amplitude of the seasonal $\mathrm{CO}_{2}$ cycle is due to terrestrial biotic activity.

Since the main goal of this paper is to study the air-sea fluxes of oxygen and learn about ocean biology, we can subtract the contribution of the land biosphere by using an appropriately scaled record of atmospheric $\mathrm{CO}_{2}$. Hereafter, we follow K-S and work with the oceanic $\mathrm{O}_{2} / \mathrm{N}_{2}$ component defined as

$$
\delta\left(\mathrm{O}_{2} / \mathrm{N}_{2}\right)_{\text {ocean }} \equiv \delta\left(\mathrm{O}_{2} / \mathrm{N}_{2}\right)+(1.1 / 0.20946) X_{\mathrm{CO} 2}
$$

where 0.20946 is the $\mathrm{O}_{2}$ mole fraction in dry air, 1.1 is the $\mathrm{O}_{2}: \mathrm{C}$ photosynthetic ratio for the terrestrial biosphere [Severinghaus, 1995], and $X_{\mathrm{CO} 2}$ is the $\mathrm{CO}_{2}$ mole fraction in parts per million by volume.

While the thermal component of air-sea $\mathrm{O}_{2} / \mathrm{N}_{2}$ flux is relatively well known [Keeling et al., 1993], the biological component (the major one) is poorly determined [Keeling et al., 1993: Bender et al., 1996]. Recent estimates of primary production have been derived by Antoine et al. [1996] using the climatological ocean color archive of Coastal Zone Color Scanner (CZCS) data. This allows a monthly description of the marine production over the global ocean. Here we use a one-dimensional (1-D) model of the global upper ocean to convert this production to a net air-sea $\mathrm{O}_{2}$ flux.

Phytoplankton in the oceans will carry out photosynthesis to produce organic carbon and $\mathrm{O}_{2}$ when light and nutrients are available. The conversion of light to organic carbon is defined by Williams [1993] as gross primary production (GPP), in terms of material productivity. This organic carbon will serve as a substrate for respiration by phytoplankton, bacteria, protozoa, and metazoa. For the entire ocean, GPP is almost exactly balanced by gross respiration when averaged over the annual cycle. The difference between GPP and the algae respiration by autotrophs over 1 day is defined as the primary production (PP), or simply "production" [Morel, 1991]. Oxygen production is derived from $\mathrm{PP}$ using an $\mathrm{O}_{2}: \mathrm{C}$ ratio discussed below.

Unfortunately, there is no direct way to estimate the fraction of this $\mathrm{O}_{2}$ production that escapes from the photic layer into the atmosphere. Three processes need to be considered when estimating the $\mathrm{O}_{2}$ air/sea exchange: (1) heterotrophic respiration consumes dissolved oxygen during remineralization of organic matter, (2) stratification of the seasonal thermocline and associated processes sequester $\mathrm{O}_{2}$-oversaturated or -undersaturated waters below the mixed layer (ML), and (3) the finite $\mathrm{O}_{2}$ air/sea exchange rate induces a time lag between euphotic zone mixed layer $\mathrm{O}_{2}$ production and export to the atmosphere.
In section 2, we present a 1-D model of $\mathrm{O}_{2}$ fluxes associated with the seasonal cycle of production which incorporates these three processes. We also apply the model to a well-measured region of the ocean for validation and calibration. Section 3 describes how the model is generalised over the whole ocean to generate the air-sea $\mathrm{O}_{2}$ flux field. In section 4, we present the three-dimensional (3D) atmospheric transport model used to simulate the seasonal atmospheric $\mathrm{O}_{2} / \mathrm{N}_{2}$. We then compare model results to available atmospheric data in section 5, discussing the constraints derived from this study for marine organic matter productivity.

\section{A One-Dimensional Ocean Model of Seasonal Dissolved $\mathrm{O}_{2}$ in the Upper Ocean}

Because the main seasonal variability of water masses occurs in the vertical dimension, we have chosen to describe the seasonal $\mathrm{O}_{2}$ variability in the upper ocean with a simple 1-D (depth) model. Variations of the mixed layer depth (MLD), especially in midlatitudes to high latitudes, cause stratification of the upper layers during the spring and summer (MLD around 10-30 m) and entrainment of subsurface water during autumn-winter (MLD around 100$300 \mathrm{~m}$ ). A good representation of MLD is therefore essential to describe the time evolution of the $\mathrm{O}_{2}$ fluxes back to the surface as the mixed layer deepens and shoals. If the seasonal thermocline includes a fraction of the upper net autotrophic part of the euphotic zone, the seasonal thermocline will be supersaturated with $\mathrm{O}_{2}$. The mixed layer will, in turn, become supersaturated upon entraining the seasonal thermocline waters when stratification breaks down in early winter. In contrast, if the seasonal thermocline extends only to the net heterotrophic part of the euphotic zone or below, it will be undersaturated. The mixed layer will then become undersaturated upon entraining these $\mathrm{O}_{2}$-undersaturated waters in late autumnwinter.

\subsection{Description of the Model}

We use a modified version of the model developed by Peng et al. [1987]. Figure 1 presents a schematic diagram of our formulation. The model is a 1-D description of ocean mixing and biology that extends from the surface to the bottom of the seasonal thermocline, i.e., the maximum mixed layer depth reached in wintertime. While the mixed layer (ML) is treated as homogeneous, no mixing occurs in the thermocline below. The layer resolution is $5 \mathrm{~m}$ in the upper $150 \mathrm{~m}, 100 \mathrm{~m}$ between 200 and $1000 \mathrm{~m}$, and $500 \mathrm{~m}$ down to $2000 \mathrm{~m}$. The integration time step is 1 day, and the model is run for 1 year following a 4 year spin-up time. Physical and biogeochemical processes taken into account are described herein.

2.1.1. Oxygen production. Oxygen production is derived from primary production estimated at different depths. We use a vertically resolved version of primary production monthly maps established by Antoine et al. [1996] from the 


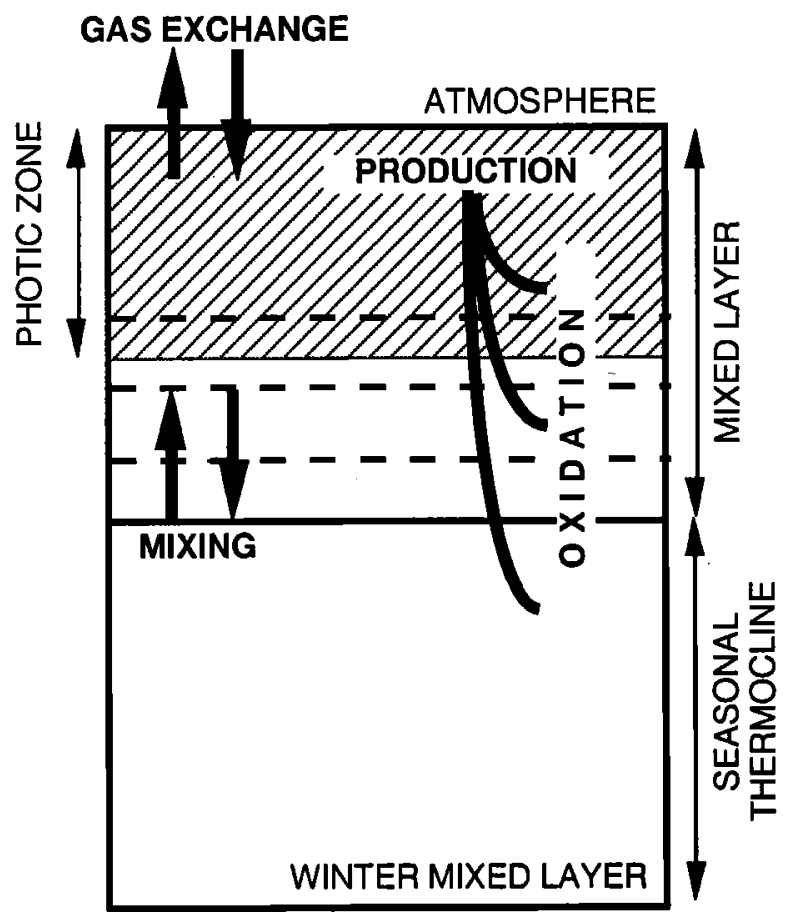

Figure 1. Schematic diagram of the one-dimensional (1-D) model used to predict oxygen fluxes. The arrows represent these fluxes.

CZCS ocean color archive (see Table 1). This enables us to capture the upper seasonal thermocline supersaturation when the photic zone extends below the bottom of the mixed layer. Following and Morel [1996], we calculate PP from sea surface irradiance, chlorophyll $a$ concentrations, and temperature. Furthermore, we discretized primary production $\operatorname{PP}(z, t)$ as a function of depth $z$ and time $t$ using depth dependence for chlorophyll [Morel and Berthon, 1989] and penetration of photosynthetic available radiation [Morel, 1991]. To get the $\mathrm{O}_{2}$ variability, at level $z$ and time $t$, we use the relation

$$
\begin{array}{r}
d \mathrm{O}_{2}(z, t) / d \mathrm{t}=\mathrm{PQ} \times \mathrm{PP}(\mathrm{z}, \mathrm{t})-\mathrm{RQ} \times \mathrm{REM}(z, t)+\mathrm{GASEX}+ \\
\text { MIXING (3) }
\end{array}
$$

where $P Q$ is the photosynthetic quotient assumed to be 1.4. This value has been inferred for the new component of production [Laws, 1991]. RQxREM $(z, t)$, where RQ is the regeneration quotient, is the consumption during remineralization, discussed below. GASEX refers to the changes in oxygen due to gas exchange at the sea-air interface and MIXING represents the redistribution of oxygen through water mixing.

2.1.2. Oxygen consumption. The consumption of oxygen occurs when organic matter is remineralized. The pathways of this oxidation are obviously complicated, since they involve all the stages of the food web (phytoplankton, zooplankton, bacteria) as well as both solid and dissolved matter. Instead of attempting to describe this, we use a very simple parameterization. The parameterization accounts for the fact that organic matter is oxidized later and deeper than it is produced. The time delay of the oxidation reflects the storage of carbon as organic matter, while the depth term accounts for the sinking of particles and/or the migration of plankton.

We therefore assume that primary production (i.e., the produced organic matter) is instantaneously redistributed downward with an exponential dependence on depth. After a delay $\tau$, all redistributed organic matter is oxidized. Formally, the remineralization $R E M$ at level $z\left(>z_{0}\right)$ and time $t$ is related to the earlier production at depth $z_{0}$ and time $t_{0}$ by

$$
R E M(z, t)=\int_{0}^{z} \exp \left[-\frac{z-z_{0}}{L_{\exp }}\right] \cdot P P\left(z_{0}, t-\tau\right) d z_{0}
$$

where the export scale length $L_{\text {exp }}$ is comparable to the product of the average sinking rate and the lifetime of organic matter. The symbol $\tau$ represents the time lag between production and remineralization. We have chosen to describe the depth dependent distribution with an exponential form rather than the power law of Martin et al. [1987], since we use it both in and below the photic zone and because we apply this profile implicitly for both dissolved and particulate organic matter. The $\mathrm{O}_{2}$ consumption is calculated from remineralization by $R Q \times$ $\operatorname{REM}(z, t)$, where the regeneration quotient is the same as the photosynthetic quotient, namely, 1.4.

Finally, we define net community production (NCP) or simply "net production" in a given layer, as production minus remineralization over the course of 1 day by

$$
N C P(z, t) \equiv \int_{t_{0}}^{t_{0}+24}[P P(z, t)-R E M(z, t)] d t
$$

Thus, in the net production zone (i.e., $N C P>0$ ), the production can be divided into two components: net community production and regenerated production (REGP) (here equal to REM). This definition is equivalent to $\mathrm{K}-\mathrm{S}$ and Williams [1993]. Finally, because $R Q=P Q$, the net $O_{2}$ production (which may be positive or negative) can be calculated, as a function of time and depth, by PQ $x$ $N C P(z, t)$. Hereafter, we refer to net $\mathrm{O}_{2}$ production in the euphotic zone as NEZP and to net $\mathrm{O}_{2}$ production in the mixed layer as NMLP, extending the definition proposed by K-S. We define the euphotic zone as the upper portion of the water column receiving $1 \%$ or more of the incident solar radiation.

2.1.3. Vertical mixing. As presented, the 1-D model accounts only for the entrainment/ventilation of dissolved $\mathrm{O}_{2}$ due to the deepening and shoaling of the mixed layer. The mixed layer depth is derived from climatological density values of Levitus [1982]. We define the base of this layer to be the depth at which the density value exceeds the $10 \mathrm{~m}$ value by $0.125 \mathrm{~kg} \mathrm{~m}^{-3}$. As expected, this definition gives a shallow mixed layer in spring and summer and a deep mixed layer in fall and winter. In practice, during autumn deepening, the subsurface waters entrained in the ML are mixed instantaneously. During vernal shoaling, 
Table 1. Data Sets Used in the Model

\begin{tabular}{|c|c|c|c|c|}
\hline & $\begin{array}{c}\text { CZCS } \\
\text { Satellite Archive }\end{array}$ & $\begin{array}{c}\text { ISCCP C2 } \\
\text { Satellite Archive }\end{array}$ & $\begin{array}{c}\text { ECMWF/WCRP } \\
\text { Level III A } \\
\text { Atmospheric Archive } \\
\end{array}$ & $\begin{array}{c}\text { Levitus } \\
\text { Hydrographic Archive }\end{array}$ \\
\hline $\begin{array}{l}\text { Years of } \\
\text { climatology }\end{array}$ & Oct.78-June 86 & Jul. 83- Dec. 90 & Jan. 90 - Dec. 90 & $\begin{array}{c}\text { Climatology described by } \\
\text { Levitus }[1982]\end{array}$ \\
\hline $\begin{array}{l}\text { Spatial and } \\
\text { temporal } \\
\text { resolution }\end{array}$ & $\begin{array}{l}\text { monthly composites } \\
512 \times 512 \text { pixels }\end{array}$ & $\begin{array}{l}\text { monthly } \\
2.5^{\circ} \times 2.5^{\circ} \\
\text { resolution }\end{array}$ & $\begin{array}{c}12 \text { hours } \\
2.5^{\circ} \times 2.5^{\circ} \text { resolution }\end{array}$ & $\begin{array}{l}\text { monthly for temperature, } \\
3 \text {-monthly for salinity; } \\
1^{\circ} \times 1^{\circ} \text { resolution }\end{array}$ \\
\hline $\begin{array}{l}\text { Derived } \\
\text { quantity(ies) }\end{array}$ & $\begin{array}{l}\text { 2-D fields of pigment } \\
\text { concentrations } \\
\left(\mathrm{mg} \mathrm{m}^{-3}\right) \text { using Csat }= \\
10^{\left(0.012^{*} \text { pixel_counts - } 1.4\right)}\end{array}$ & $\begin{array}{l}\text { 2-D fields of } \\
\text { cloudiness }\end{array}$ & $\begin{array}{c}\text { 2-D fields of } 10 \mathrm{~m} \\
\text { wind speed; oxygen } \\
\text { exchange coefficient } \\
\text { from Liss and Merlivat } \\
\text { [1986] scaled by } 1.7 \\
\text { (see text). }\end{array}$ & $\begin{array}{l}\text { 3D fields of temperature } \\
\text { and salinity; mixed layer } \\
\text { depth using density } \\
\text { departure of } 0.125 \mathrm{~kg} \mathrm{~m}^{-3} \\
\text { from } 10 \mathrm{~m} \text { depth reference. }\end{array}$ \\
\hline $\begin{array}{l}\text { Filling of missing } \\
\text { data }\end{array}$ & $\begin{array}{c}\text { as described by } \\
\text { Antoine et al. }[1996] \\
\text { plus corrections } \\
\text { poleward of } 30^{\circ} \mathrm{S} \\
\text { and filling winter } \\
\text { months poleward of } \\
\text { circa } 60^{\circ}\end{array}$ & & & $\begin{array}{l}\text { few missing data, } \\
\text { objective mapping }\end{array}$ \\
\hline References & $\begin{array}{c}\text { Esaias et al. }[1986] \\
\text { Feldman et al. } \\
{[1989]} \\
\text { Sullivan et al. } \\
{[1993]} \\
\text { Yoder et al. }[1993] \\
\end{array}$ & $\begin{array}{c}\text { Rossow et al. } \\
\text { [1988] }\end{array}$ & Bengtsson et al. [1982] & Levitus [1982] \\
\hline
\end{tabular}

Abbrevations are CZCS, coastal zone color scanner, ISCCP, International Satellite Cloud Climatology Project; ECMWF, European Center for Medium-Range Weather Forecasts, WCRP, World Climate Research Program; and Levitus, Levitus [1982].

waters at the base of the ML are incorporated into the stratified layers of the seasonal. Because we used thin layers in the first $100 \mathrm{~m}$, the numerical diffusivity is limited to $5 \mathrm{~m}$.

The simplifying assumptions of our model can introduce significant artifacts. Mixing that occurs in the seasonal thermocline (which we take as stratified) is neglected. No 3-D advection or horizontal mixing is taken into account. Finally, the carbon and the oxygen cycles are not closed within the 1-D model, as part of the downward export of organic matter is lost through the bottom of the seasonal thermocline. In the real ocean, the oxygen depletion caused by the oxidation of this organic matter in layers below the base of the seasonal thermocline is redistributed over large lateral distances. As a consequence, annually averaged fluxes at any given location are nonzero. The $\mathrm{O}_{2}$ flux from ocean to atmosphere is generally positive at low latitudes and negative at midlatitudes to high latitudes where waters of the main thermocline (and below) outcrop.

Since organic matter leaves the seasonal thermocline, the model neglects any oxygen demand when the resulting undersaturated waters are ventilated. Therefore, to close the model oxygen budget on a global scale, we assume that for each extratropical hemisphere, suboxic water resulting from $\mathrm{O}_{2}$ consumption below the seasonal thermocline (from $11^{\circ}$ to $90^{\circ}$ ) is redistributed and ventilated with a uniform flux during the fall-winter month of each year (October through March in the northern hemisphere, April through September in the southern hemisphere). The ventilation occurs uniformly over the world oceans poleward of $49^{\circ}$. This admittedly crude approximation was chosen to include the high latitudes where lateral ventilation is known to 
occur (the North Atlantic and the Southern Oceans). Over these high latitudes regions, we simply distribute the $\mathrm{O}_{2}$ demand due to remineralization during the 6 month period. Production in the intertropical belt $\left(11^{\circ} \mathrm{S}-11^{\circ} \mathrm{N}\right)$ is assumed to be ventilated in the same region and to have no seasonality.

We are aware that ventilation is neither constant in time nor uniformly distributed. Unfortunately, the dearth of observational constraints makes any more refined estimates of the temporal and spatial scales of ventilation speculative. Clearly, we will be able to use far more realistic parameterizations of nonlocally balanced fluxes as regions and strengths of lateral ventilation become better documented on a global scale. Nonetheless, this simple assumption is useful to understand $\mathrm{O}_{2} / \mathrm{N}_{2}$ atmospheric variations. As we see in section 5, the essential features are captured by the model.

2.1.4. Gas exchange. The net oxygen outgasing from sea to air $F_{\mathrm{O} 2}\left(\mathrm{~mol} \mathrm{~m} \mathrm{~m}^{-2} \mathrm{yr}^{-1}\right)$, at time $t$, is driven by the difference of partial pressure in water and air.

$$
F_{O_{2}}{ }^{(t)}=k\left[V_{10 m}{ }^{(t), T(t)] S_{O_{2}}}(T(t)]\left[p_{O_{2}}(0, t)-0,20946\right]\right.
$$

The effects of bubble-induced supersaturation have been neglected. The kinetic factor $k$ is the piston velocity for oxygen (meters per year). We use the Liss and Merlivat [1986] relationship using the $\mathrm{O}_{2}$ molecular diffusion [Jenkins and Goldman, 1985] and linking piston velocity to temperature $T$ and $10-\mathrm{m}$ wind speed $V_{10 \mathrm{~m}}$. As described by Ramonet and Monfray [1996], we scaled the Liss and Merlivat relation by a factor 1.7 to agree with the global exchange of ${ }^{14} \mathrm{CO}_{2}$. The $\mathrm{O}_{2}$ solubility $\mathrm{S}_{02}\left(\mathrm{~mol} \mathrm{~m}^{-3} \mathrm{~atm}^{-1}\right)$ is computed from Weiss [1970]. The other terms represent the $\mathrm{O}_{2}$ partial pressure (atmospheres) in surface water $\left(p_{\mathrm{O} 2}\right)$ and the $\mathrm{O}_{2}$ partial pressure in air (0.20946).

The temperature dependence of the solubility in the model allows natural simulation of the solubility-driven effects: degasing in spring/summer, and ingasing in fall/winter. We also accounted for the ice-covered surfaces where sea-air exchange is forbidden. When averaged zonally, the oxygen fluxes due to gas solubility are found to be very similar to the ones described by Keeling et al. [1993].

In summary, the 1-D model simulates the seasonal evolution of oxygen air-sea fluxes using ocean color, cloudiness, surface wind speed, temperature and density profiles of the upper ocean. We employ only two free parameters $\left(L_{\text {exp }}, \tau\right)$. Both describe the respiration of organic matter.

\subsection{Application at the North Atlantic Bloom Experiment Site}

To test the behavior of the model, we simulated conditions at the North Atlantic Bloom Experiment (NABE) site $\left(48^{\circ} \mathrm{N}, 20^{\circ} \mathrm{W}\right)$ in the northern Atlantic where intensive carbon and oxygen budget studies were made during a bloom event [Bender et al., 1992]. Climatological

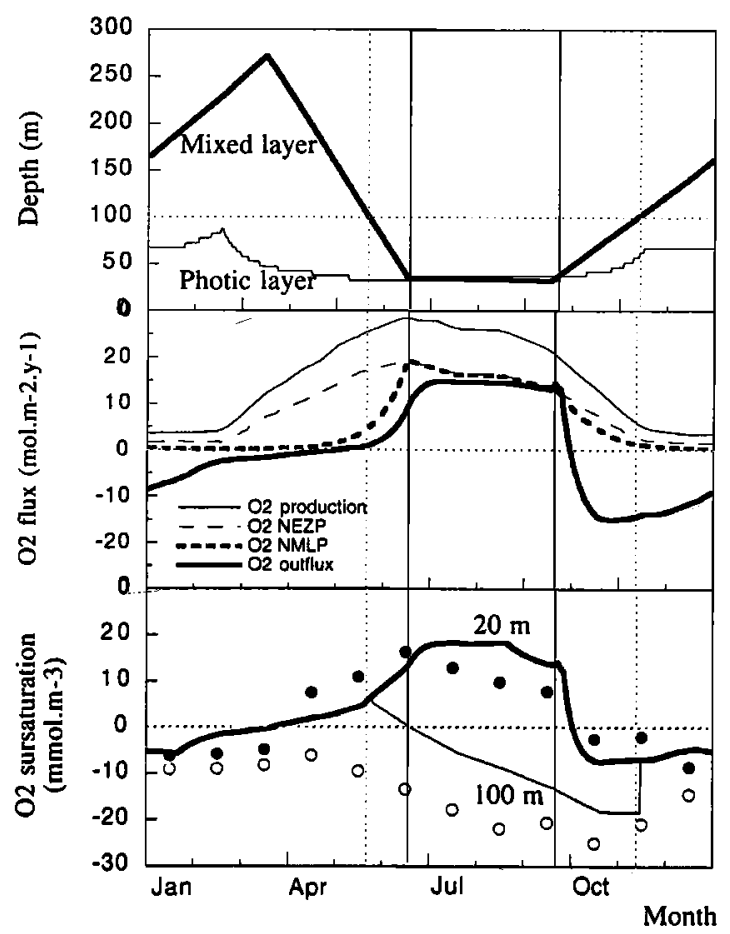

Figure 2. $\mathrm{O}_{2}$ seasonal cycle at the North Atlantic Bloom Experiment site $\left(48^{\circ} \mathrm{N}, 20^{\circ} \mathrm{W}\right)$ showing mixed layer depth, photic zone depth, $\mathrm{O}_{2}$ flux due to primary production (thin solid line), net production in photic zone (thin dashed line), net production in mixed layer (thick dashed line), and $\mathrm{O}_{2}$ sea to air exchange (thick solid line). Also, oxygen supersaturation at $20 \mathrm{~m}$ and $100 \mathrm{~m}$ depths is displayed both for data (circles) and the 1-D model (lines). Finally, vertical lines indicate when mixed layer depth crosses the photic depth (solid lines) or the $100 \mathrm{~m}$ level (dotted lines).

archives (CZCS), International Satellite Cloud Climatology Project (ISCCP), European Center for Medium-Range Weather Forecasts (ECMWF), and Levitus hereinafter referred to as Levitus [1982]) used to force the model are summarised in Table 1. Figure 2 displays the major driving variables of the 1-D model (mixed layer depth, photic depth and $\mathrm{O}_{2}$-production). Computed $\mathrm{O}_{2}$ net production in the photic zone (NEZP) and the mixed layer (NMLP), and $\mathrm{O}_{2}$ air-sea fluxes are also shown. We assumed an export length $L_{\exp }$ of $50 \mathrm{~m}$ and no time lag for the remineralization $(\tau=0)$. It is worth noting that in the presence of a deep mixed layer, $\mathrm{O}_{2}$ outgasing is inhibited despite significant springtime production. If the mixed layer depth is much greater than the photic depth, two processes occur. (1) A significant fraction of organic matter cannot escape the mixed layer and is remineralized below the photic zone, consuming the oxygen produced higher in the water column. Thus NMLP is much lower than NEZP; (2) When the ML exceeds $100 \mathrm{~m}$, there is a significant time lag between $\mathrm{O}_{2}$ production and outgasing (up to 1.5 months). In summer, a large fraction of the net $\mathrm{O}_{2}$ production is 
exported to the atmosphere, while in autumn, after a short $\mathrm{O}_{2}$ supersaturation of subsurface waters, ventilation of undersaturated waters takes place. We now discuss the amplitude and the phase that result from these processes and are parameterized in terms of $L_{\text {exp }}$ and $\tau$.

$L_{\exp }$ is a critical value that determines the $f$ ratio of net production to production (NCP/PP) for a given model layer or depth. At steady state, the $f$ ratio corresponds to the fraction of production exported from the base of the given. An export length of $50 \mathrm{~m}$ would lead to an $f$ ratio close to 0.07 at $150 \mathrm{~m}$ depth. If we consider only the photic layer, the $f$ ratio ranges from 0.4 in wintertime to 0.65 in summer. In particular, if surface chlorophyll increases (a bloom), the photic layer depth decreases and a smaller fraction of production is remineralized in it, inducing the expected increase in the $f$ ratio. Observations, made by Bender et al. [1992] during a 13-day bloom event in May, are consistent with these predictions. They found that (1) the net production in the photic layer was around half of the production; (2) roughly half of this net production was exported, the rest remaining in the photic layer; (3) the export production at $150 \mathrm{~m}$ was roughly 0.07 of the net photic production.

To check the behavior of $\mathrm{O}_{2}$ in the regions of production and remineralization, we plot both the predicted and observed $\mathrm{O}_{2}$ supersaturation values at $20 \mathrm{~m}$ and $100 \mathrm{~m}$ depths (see Figure 2). The observations are recent monthly analyses of the National Oceanographic Data Center (NODC) data set [Najjar and Keeling, 1997]. The agreement of the amplitudes of the signals are encouraging. However, it seems the onset of stratification occurs earlier in the spring than the model (driven by the Levitus ML depth) would suggest.

Figure 3 presents sensitivity tests of the air-sea fluxes when the effect of gas solubility is not included. If we

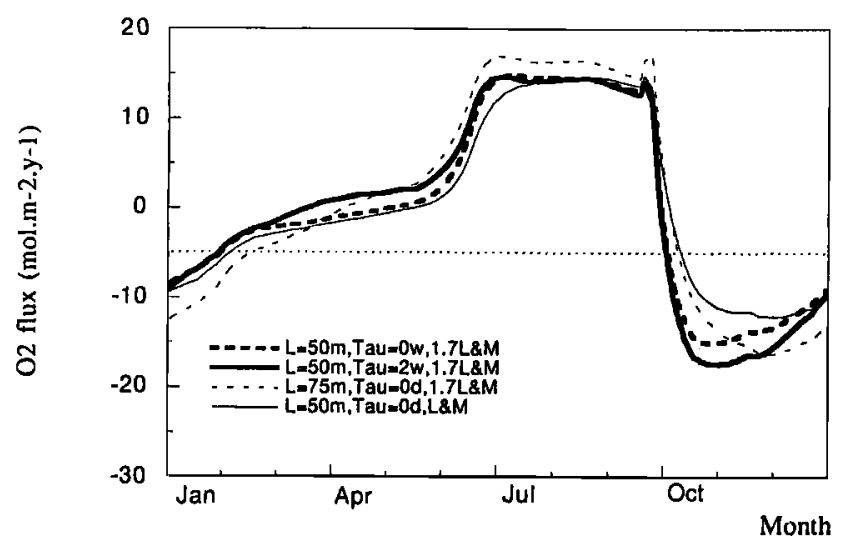

Figure 3. Sensitivity study of oxygen air-sea fluxes at the NABE site. The standard case (thick solid line) corresponds to an export length of $50 \mathrm{~m}$ and a storage time lag of 2 weeks. The following sensitivities are displayed: increased export length $75 \mathrm{~m}$ (thin dashed line), instantaneous remineralization (thick dashed line), and reduced gas exchange (thin solid line) without ${ }^{14} \mathrm{C}$ calibration (see text). introduce a storage of organic matter $\tau$ of 2 weeks before remineralization occurs, the outgasing of $\mathrm{O}_{2}$ is slightly increased. If $\tau$ is greater than a few months, the effects on $\mathrm{O}_{2}$ outgasing can be substantial, but such a large value causes unrealistically durable organic matter to be produced daily. An increase of the export length $L_{\exp }$ will significantly increase the amplitude of the air-sea fluxes, but the $f$ ratio for the photic zone then reaches unrealistic values (as high as 0.75 during summer). At the other extreme, a small export length implies a near-surface remineralization with very little export at $150 \mathrm{~m}$. Finally, reducing the gas exchange coefficient by a factor of 1.7 (i.e., without the aforementioned calibration) delays the $\mathrm{O}_{2}$ outgasing by about 2 weeks. On the basis of these data, we simply use $L_{\text {exp }}=50 \mathrm{~m}$ and $\tau=2$ weeks for all of the modeling that follows. We recognize that in the real world, the capacity of marine biomass to store and export carbon varies from the oligotrophic regime to the eutrophic regime. In the interest of simplicity however, in our present study we use NABE site data to constrain out choice of the $f$ ratio and of the export length and assume that these values are suitable to other regions as well.

\section{Application of the One-Dimensional Model Over the Globe Using Clinuatological Archives}

We have extended the 1-D model to the global open ocean using the same horizontal resolution $\left(7.5^{\circ} \times 7.5^{\circ}\right)$ as the atmospheric transport model (TM2) described below. The production PP has been computed monthly from CZCS (surface chlorophyll), ISCCP (cloudiness), and Levitus (T) archives (see Table 1). In areas poorly covered by CZCS, particularly in gyres and midlatitudes to high latitudes, ocean color was interpolated in time and space following the procedure of Antoine et al. [1996]. In the southern oceans, south of $30^{\circ} \mathrm{S}$, we corrected the satellite underestimation by the algorithm proposed by Sullivan et al. (1993, Figure 2a), based on 6173 in situ measurements of surface chlorophyll concentrations. The oxygen piston velocity is computed at 12-hour intervals from ECMWF wind fields for the year 1990 using a resolution of $2.5^{\circ} \mathrm{x}$ $2.5^{\circ}$ [see Ramonet and Monfray, 1996]. The depth of the mixed layer is deduced from the monthly temperature fields and the seasonal salinity fields of the Levitus data set. All forcing fields were gridded over the $7.5^{\circ}$ resolution of the globalized 1-D model and interpolated linearly in time to give daily values. Finally to close the oxygen budget below the seasonal thermocline, we follow the crude procedure described above (see section 2.1.3) to take into account the lateral ventilation of deep waters at midlatitudess and high latitudes during fall and winter.

In summary, we compute the $\mathrm{O}_{2}$ fluxes $\left(\mathrm{F}_{\mathrm{O} 2}\right)$ by taking into account four processes: (1) photosynthetic production, (2) consumption in the mixed layer and seasonal thermocline, (3) the solubility pump (solubility-driven flux), and (4) lateral ventilation of deep waters in midlatitudes and high latitudes. 


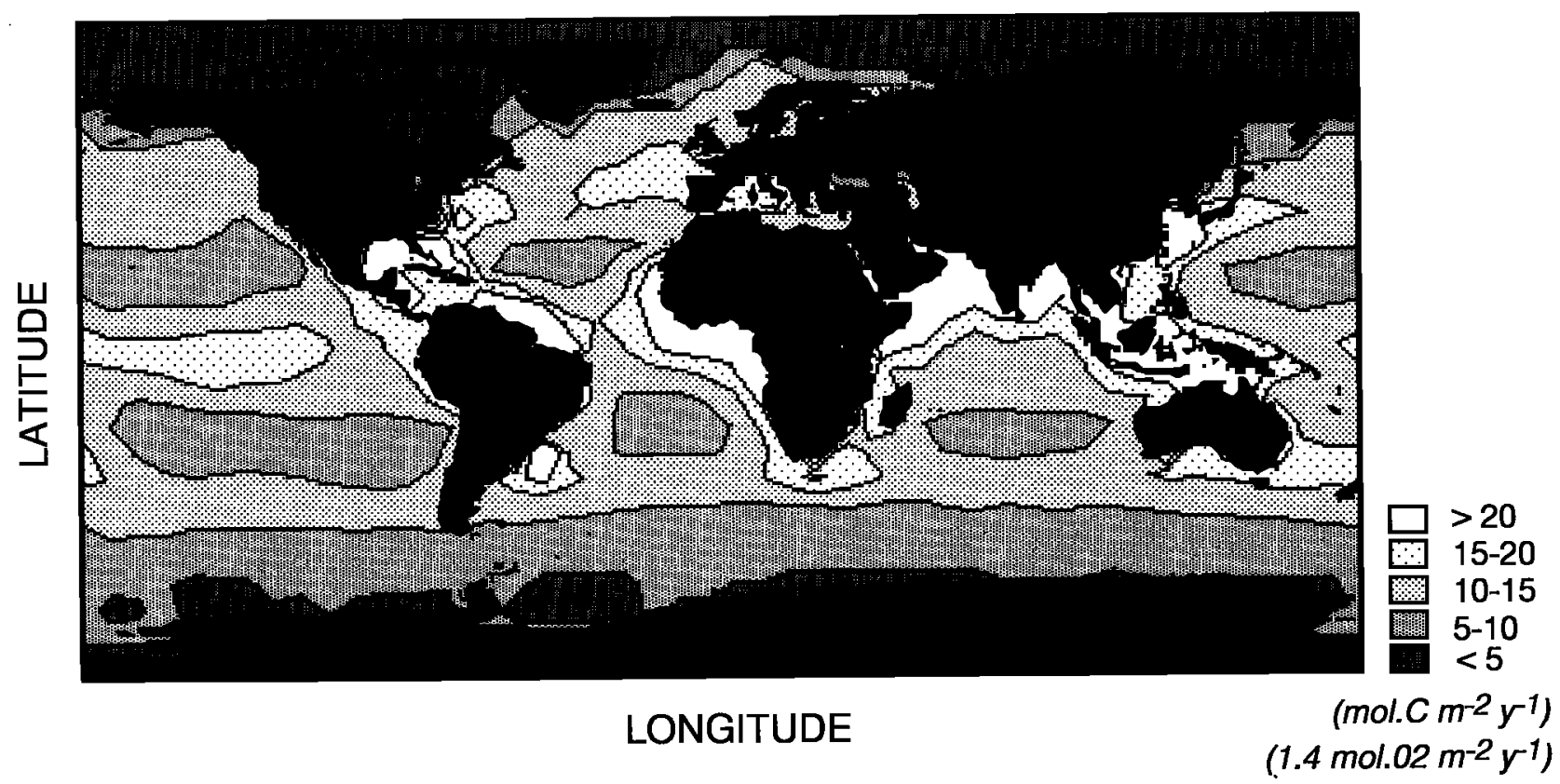

Figure 4a. Primary production (mol C m $\mathrm{yr}^{-1}$, equivalent to $1 . / 1.4 \mathrm{~mol} \mathrm{O}_{2} \mathrm{~m}^{-2} \mathrm{yr}^{-1}$ ) derived from the light-photosynthesis algorithm described by Antoine and Morel [1996].

This highly simplified representation of the ocean allows us to mimic the gradual ventilation of the seasonal thermocline, of the main thermocline, and of deep waters. The annual distribution of vertically integrated PP, which sums to a value of $38 \mathrm{Gt} \mathrm{C} \mathrm{yr}^{-1}$, is shown in Figure $4 \mathrm{a}$ and resembles the estimate of Antoine et al. [1996] as expected. The net production (NCP) in the photic layer is found globally to be half of the total production (19 Gt $\mathrm{C} \mathrm{yr}^{-1}$ ),

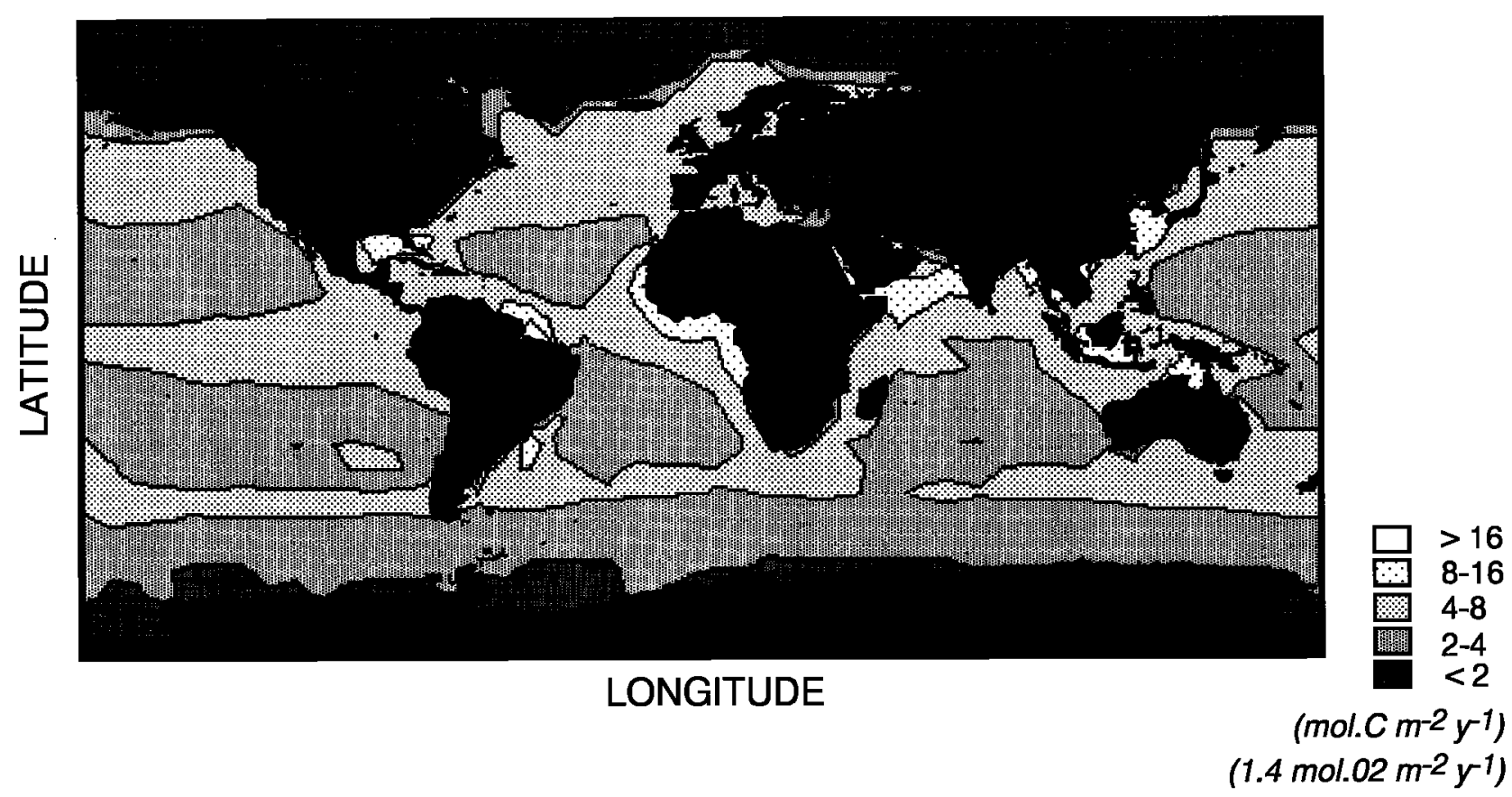

Figure 4b. Net production in the euphotic zone (nol $\mathrm{C} \mathrm{m}^{-2} \mathrm{yr}^{-1}$, equivalent to $1.4 \mathrm{~mol} \mathrm{O}_{2} \mathrm{~m}^{-2} \mathrm{yr}^{-1}$ ) from the 1-D model described in the text. 


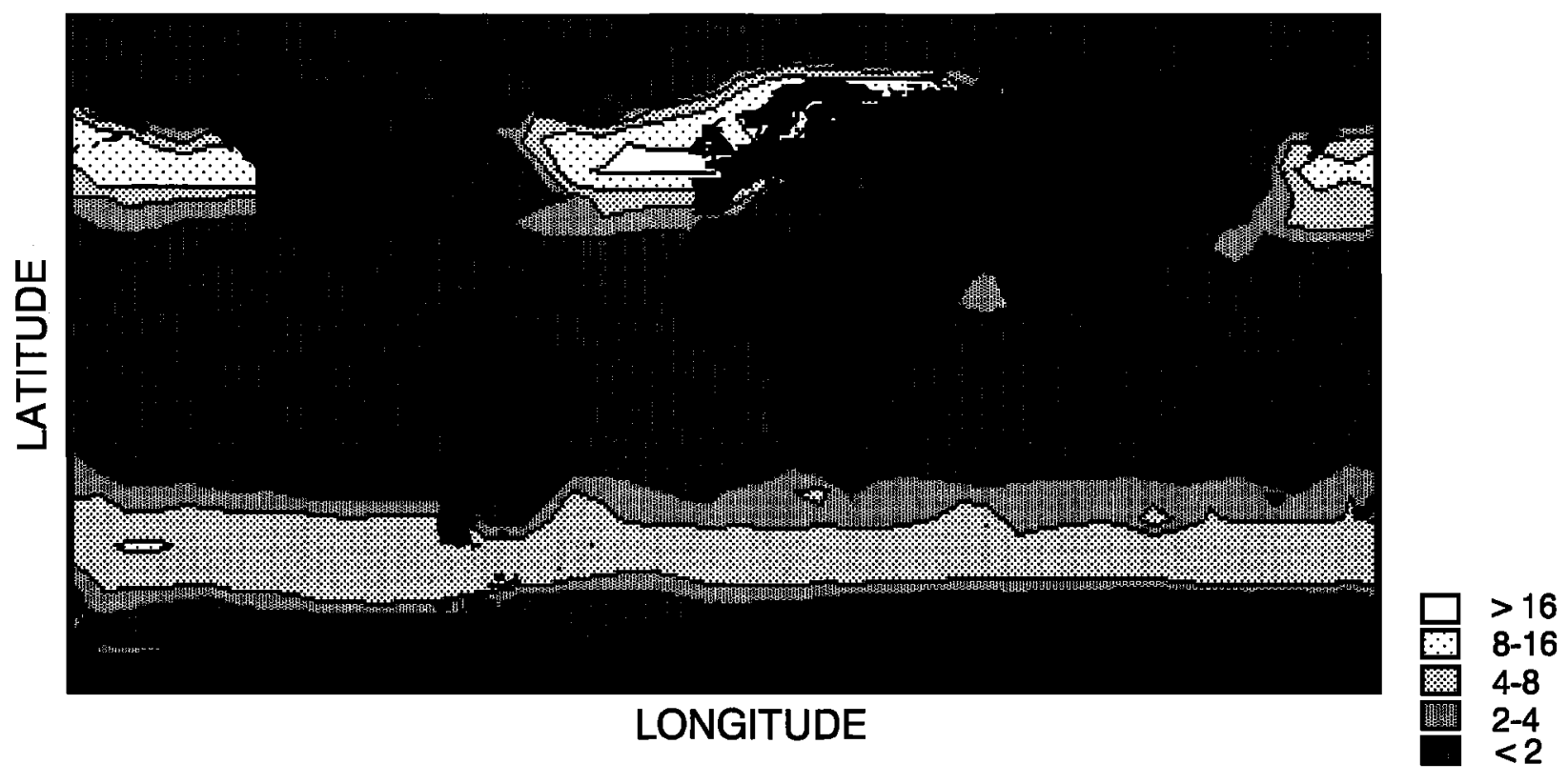

$\left(m o l .02 m^{-2} y^{-1}\right)$

Figure 5. Seasonal net outflux of oxygen (see text for definition) in $\mathrm{mol}_{2} \mathrm{~m}^{-2} \mathrm{yr}^{-1}$.

corresponding to $4.3 \mathrm{~mol} \mathrm{C} \mathrm{m} \mathrm{mr}^{-1}$ and to a net oxygen

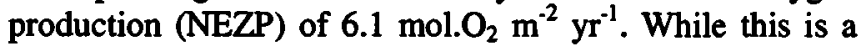
fairly high estimate, we note that it includes both production of dissolved and particulate organic matter. Furthermore, this value refers to the thin layer of the photic zone (less than $50 \mathrm{~m}$ in eutrophic depth). If we consider instead the entire mixed layer, net production decreases significantly to $14 \mathrm{Gt} \mathrm{C} \mathrm{yr}^{-1}\left(4.5 \mathrm{~mol} \mathrm{O}_{2} \mathrm{~m}^{-2} \mathrm{yr}^{-1}\right)$. The annually averaged distribution of net production in the photic layer is outlined in Figure $4 \mathrm{~b}$. The same distribution applies for carbon (NCP) as for $\mathrm{O}_{2}(\mathrm{NEZP}=\mathrm{PQ} * \mathrm{NCP})$. The same general patterns as for production are found: high values in the North Pacific and North Atlantic, moderate values in the equatorial belt and sub-Antarctic zone, and low values in gyres. Moreover, we can note that the $f$ ratio for the photic zone is lower in gyres (around 0.3) and higher in eutrophic areas (up to 0.7). Finally, the lateral ventilation of deep waters in midlatitudes and high latitudes that closes the budget corresponds to the remineralization of $2.7 \mathrm{Gt} \mathrm{C} \mathrm{yr}^{-1}$ in the northern hemisphere and $2.4 \mathrm{Gt} \mathrm{C} \mathrm{yr}^{-1}$ in the southern hemisphere.

To characterize the air-sea exchange of $\mathrm{O}_{2}$, we defined the seasonal net outflux (SNO) of oxygen as the biological component of the cumulative net $\mathrm{O}_{2}$ flux into the atmosphere when the air-sea flux exceeds the mean annual flux. This definition is equivalent to the definition of total seasonal net outgasing proposed by K-S when the mean annual flux is equal to zero. SNO is shown in Figure 5. We clearly see that the contribution from low latitudes to the seasonality is weak, while for middle and high latitudes a strong seasonality occurs (up to $15 \mathrm{~mol} \mathrm{O}_{2} \mathrm{~m}^{-2} \mathrm{yr}^{-1}$ for the
North Atlantic) owing in part to lateral ventilation. For the whole ocean, SNO averages $2.5 \mathrm{~mol} \mathrm{O}_{2} \mathrm{~m}^{-2} \mathrm{yr}^{-1}$, a value much closer to the averaged net production in the mixed layer (NMLP) than in the photic zone (NEZP).

As suggested by K-S, the relationship between the seasonal net outgasing and the net euphotic zone production can be characterized by the ratio $G$ (defined as SNO/NEZP). Averaged globally, $G$ is equal to 0.4 , slightly lower than the a priori value of 0.5 proposed by K-S. When this definition is extended to smaller scales than the hemisphere, spatial variations of $G$ are important. If $G$ is close to zero, oxygen produced shows little seasonality or remains below the seasonal thermocline. When $G$ is close to unity, it indicates that either excess oxygen enters the atmosphere or, in the case of lateral ventilation at high latitudes, the oceanic surface waters constitute a large oxygen demand for the atmosphere.

Figure 6 displays the zonally averaged values of $g$ as a function of latitude. Values of $G$ increase from nearly zero in the tropics to 1.5 at latitudes around $60^{\circ}$. Values of $G$ greater than 1 are brought about by the strong seasonal uptake of $\mathrm{O}_{2}$ by the ocean in middle to high latitudes due to nonlocally balanced wintertime ventilation. Therefore we also show in Figure 6 the $G$ in the absence of lateral ventilation.

Finally, we also use the model to derive the seasonal airsea fluxes of $\mathrm{N}_{2}\left(F_{\mathrm{N} 2}\right)$, by simply removing all biological processes and taking into account only solubility-driven processes coupled to finite gas exchange (as for $\mathrm{O}_{2}$ ), using the $\mathrm{N}_{2}$ solubility from Weiss [1970] and the $\mathrm{N}_{2}$ molecular diffusion of Jenkins and Goldman [1985]. In this way, we 


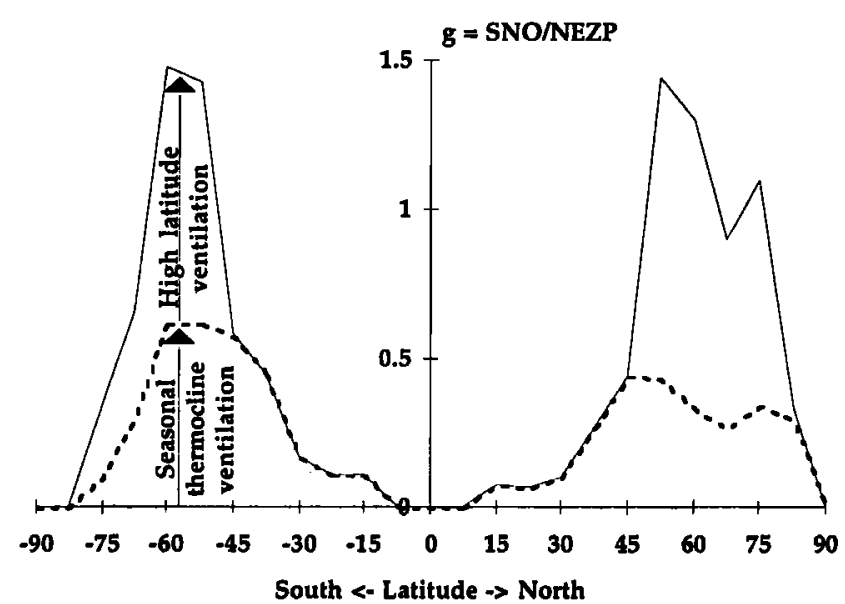

Figure 6. Zonal mean ratio of seasonal net outgasing over net production in the euphotic zone. Without deep lateral ventilation (dashed line) the ratio is always smaller than 1 . When lateral ventilation is included (solid line), the ratio exceeds 1 for high-latitude regions.

generate self-consistent air-sea fluxes of $\mathrm{O}_{2}$ and $\mathrm{N}_{2}$ from CZCS, ISCCP, ECMWF and Levitus archives. The use of a 3-D atmospheric transport model, described in section 4, allows simulation of the seasonal cycle of atmospheric $\mathrm{O}_{2} / \mathrm{N}_{2}$.

\section{Description of the Three-Dimensional Atmospheric Transport Model}

The atmospheric model used in this study is the off-line 3-D chemical tracer model called TM2, developed at the Max Planck Institute in Hamburg, and described by Heimann and Keeling [1989], and Heimann [1995]. The model's grid resolution is $7.5^{\circ} \times 7.5^{\circ}$, and there are nine vertical layers. The top two model layers are in the stratosphere, while layers below describe the troposphere. The wind fields used by the TM2 are analyzed winds. Consequently, the model is able to simulate the meteorology for a particular year.

In this study we use the wind fields from the European Centre for Medium range Weather Forecasts for the year 1990 as input to the model. In this paper we choose not to examine the interannual variations of $\mathrm{O}_{2} / \mathrm{N}_{2}$ caused by the difference in wind strength or wind direction among the years 1994 to 1997. Previous tests with winds from 1990 to 1995 (P. Bousquet, unpublished results 1996) have shown that wind fields from different years have little effect on the seasonal variations of $\mathrm{CO}_{2}$. The model was run for 5 years with perpetual 1990 meteorological fields and we analyzed the last year only. Hence a 4-year spin-up of the model ensures that the seasonal variations in $\mathrm{O}_{2} / \mathrm{N}_{2}$ are in a quasi steady state.

The formulation used in the model is based on a slope scheme developed by Russel and Lerner [1981]. 'The convection scheme is based on the work of Tiedtke [1989].
This scheme computes mass fluxes in updrafts and thus facilitates tracking of changes in tracer vertical redistribution following a convective event. The relative strength of the convection compared to other schemes is discussed by Mahowald et al. [1995]. One of their conclusions is that TM2 convection tends to vertically mix tracers more vigorously than other formulations. They base this judgment upon tropical $\mathrm{CO}$ measurements taken during the Amazon Boundary Layer Experiment 2A (ABLE2A). Unfortunately, no existing atmospheric measurements are frequent and extensive enough to justify choosing one of these convection schemes.

Features of the long-range transport in the TM2 model have been studied by simulations of ${ }^{85} \mathrm{Kr}$. The ability of the model to reproduce the meridional gradients of ${ }^{85} \mathrm{Kr}$ measured across the Atlantic in spring and winter indicate that the interhemispheric transport is simulated well by the model. Intrahemispheric and regional transport studies have focused on ${ }^{222} \mathrm{Rn}$, a radioactive gas produced from soil with a well-defined global source and a half-life of 3.8 days [Heimann et al., 1990]. The model's representation of longrange transport and of convection has been compared with 19 other models [Jacob et al., 1997], again using ${ }^{222} \mathrm{Rn}$ distributions. Furthermore, the model is able to reproduce free tropospheric ${ }^{222} \mathrm{Rn}$ concentrations measured in flights over coastal and oceanic regions of both hemispheres during the Tropospheric Ozone II (TROPOZ II) campaign that took place in January 1991 [Ramonet et al., 1996].

The relative variability of atmospheric $\mathrm{O}_{2} / \mathrm{N}_{2}$ ratio due to oceanic processes is derived from (2) as

$$
\delta\left(\mathrm{O}_{2} / \mathrm{N}_{2}\right)_{\text {ocean }} \equiv \delta\left(\mathrm{O}_{2}\right)_{\text {ocean }}-(0.20946 / 0.78084) \delta\left(\mathrm{N}_{2}\right)_{\text {ocean }}
$$

where $0.20946 / 0.78084$ is the $\mathrm{O}_{2} / \mathrm{N}_{2}$ mole ratio in dry air. The terms $\delta\left(\mathrm{O}_{2}\right)_{\text {ocean }}$ and $\delta\left(\mathrm{N}_{2}\right)_{\text {ocean }}$ represent the atmospheric variations induced by the air-sea fluxes of $\mathrm{O}_{2}$ $\left(F_{\mathrm{O}_{2}}\right)$ and $\mathrm{N}_{2}\left(F_{\mathrm{N}_{2}}\right)$ borne by the atmospheric transport model TM2. The oceanic component of $\mathrm{CO}_{2}$ (see (2)) has been neglected in our study. This omission is less than 5 per meg because the oceanic contribution to $\mathrm{CO}_{2}$ is lower than 1 ppmv (not shown here; see also Ramonet [1994]).

Finally, we account for sea ice by allowing the sea-air exchange to take place only from the fraction of the grid box not covered by ice. This fractional ice cover is a monthly data set where ice concentration field was derived from consolidating the monthly northern hemispheric sea ice concentrations of Walsh [1978] and the southern hemispheric sea ice, concentration of Zwally et. al. [1983]. While sea ice concentrations range from 0.0 to 1.0 , we choose a threshold of 0.2 to indicate the presence of open water.

\section{Results and Discussion}

In this section, we present the model results and compare them to observations. To first order, during spring and summer, ocean surface waters are replenished in oxygen. 


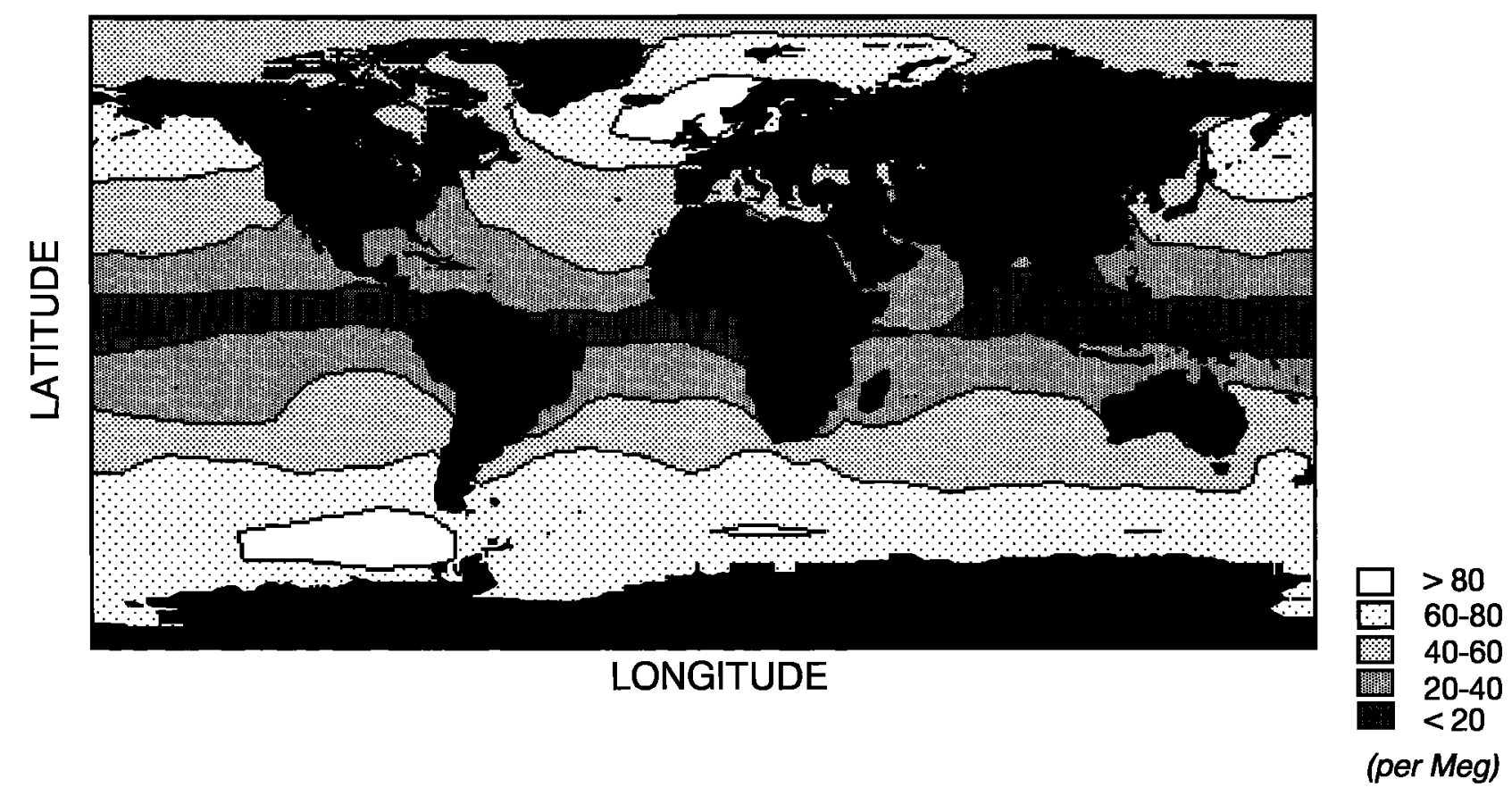

Figure 7. Contribution of the ocean to the yearly seasonal amplitude of $\mathrm{O}_{2} / \mathrm{N}_{2}$ "per meg", i.e. multiplied by $10^{6}$

$$
\delta\left(\mathrm{O}_{2} / \mathrm{N}_{2}\right)=10^{6}\left[\left(\mathrm{O}_{2} / \mathrm{N}_{2}\right)_{\text {sample }} /\left(\mathrm{O}_{2} / \mathrm{N}_{2}\right)_{\text {reference }}-1\right]
$$

in surface air.

This drives a transfer from the ocean to the atmosphere and the atmospheric $\mathrm{O}_{2} / \mathrm{N}_{2}$ ratio rises up to a yearly maximum in late summer and early autumn. During fall and winter, $\mathrm{O}_{2}$-undersaturated waters are ventilated. There is a return flux of $\mathrm{O}_{2}$ from air to sea and the $\mathrm{O}_{2} / \mathrm{N}_{2}$ ratio of air decreases until late winter-early spring, when it reaches a minimum.

\subsection{Surface Seasonal Variations of Oceanic $\mathrm{O}_{2} / \mathrm{N}_{2}$}

Figure 7 displays the model prediction of the yearly atmospheric $\mathrm{\delta O}_{2} / \mathrm{N}_{2}$ amplitude calculated from the simulated monthly means, in per meg, due to exchange with the oceans (see (1) and (2)).

The main features of the yearly amplitude are a maximum in the Southern Ocean from $30^{\circ} \mathrm{S}$ to $70^{\circ} \mathrm{S}$, a weak amplitude in the tropics, and, a secondary maximum over northern hemisphere midlatitude and high latitude oceanic regions, particularly over the North Atlantic. The highest seasonal amplitudes are found poleward of $38^{\circ}$ where the oxygen demand at the base of the model is redistributed during winter. The model marine biosphere contribution to the seasonal signal exceeds 60 per meg around $50^{\circ} \mathrm{N}$ in the Pacific and exceeds 80 per meg at $65^{\circ} \mathrm{N}$ near Iceland. In the southern hemisphere, the highest variations can reach 80 per meg at $60^{\circ} \mathrm{S}$. Generally, the largest contribution of the marine biosphere to the seasonal amplitudes is found south of $30^{\circ} \mathrm{S}$, where most of the Earth's surface is covered by oceans. The large surface area overcomes the relatively low net production per unit area in this region (see Figure $4 b$ ).
The seasonal variations due to the marine biosphere can be compared with the ones obtained by Keeling et al. [1993]. In the northern hemisphere, the model of these authors predicts an amplitude of 40 per meg at $33^{\circ} \mathrm{N}$, of 50 per meg at $58^{\circ} \mathrm{N}$, and of 70 per meg between $33^{\circ} \mathrm{S}$ and $58^{\circ} \mathrm{S}$. In contrast, our modeling work predicts an increase in the seasonal signal between $33^{\circ} \mathrm{S}$ and $58^{\circ} \mathrm{S}$.

\subsection{Comparison With Observations}

We have evaluated our simulation at five monitoring sites: Barrow $\left(71^{\circ} \mathrm{N}, 156^{\circ} \mathrm{W}\right)$, La Jolla $\left(33^{\circ} \mathrm{N}, 117^{\circ} \mathrm{W}\right)$, Mauna Loa Observatory $\left(20^{\circ} \mathrm{N}, 156^{\circ} \mathrm{W}\right)$, Cape Grim $\left(40^{\circ} \mathrm{S}\right.$, $\left.144^{\circ} \mathrm{E}\right)$, and Baring Head $\left(41^{\circ} \mathrm{S}, 170^{\circ} \mathrm{E}\right)$. At La Jolla and Mauna Loa, measurements of $\mathrm{O}_{2} / \mathrm{N}_{2}$ and $\mathrm{CO}_{2}$ were made by R. Keeling (personal communication, 1996); at Barrow, Cape Grim and Baring Head, $\mathrm{O}_{2} / \mathrm{N}_{2}$ measurements have been collected by Bender et al. [1996, 1998]. Carbon dioxide measurements at Barrow, Cape Grim, and Baring Head are the ones taken by $\mathrm{T}$. Conway et al. at the Climate Monitoring and Diagnostics Laboratory, National Oceanic and Atmospheric Administration. The measurements are not made from the same flasks as the $\mathrm{O}_{2} / \mathrm{N}_{2}$ measurements at these sites.

In order to extract the oceanic contribution to the seasonal signal in $\mathrm{O}_{2} / \mathrm{N}_{2}$ at the different sites (Figure 8 for Cape Grim), we follow three steps. In step 1, the interannual trend in $8 \mathrm{O}_{2} / \mathrm{N}_{2}$ and $\mathrm{CO}_{2}$ records are taken out to obtain only the seasonal variations, following the procedure 


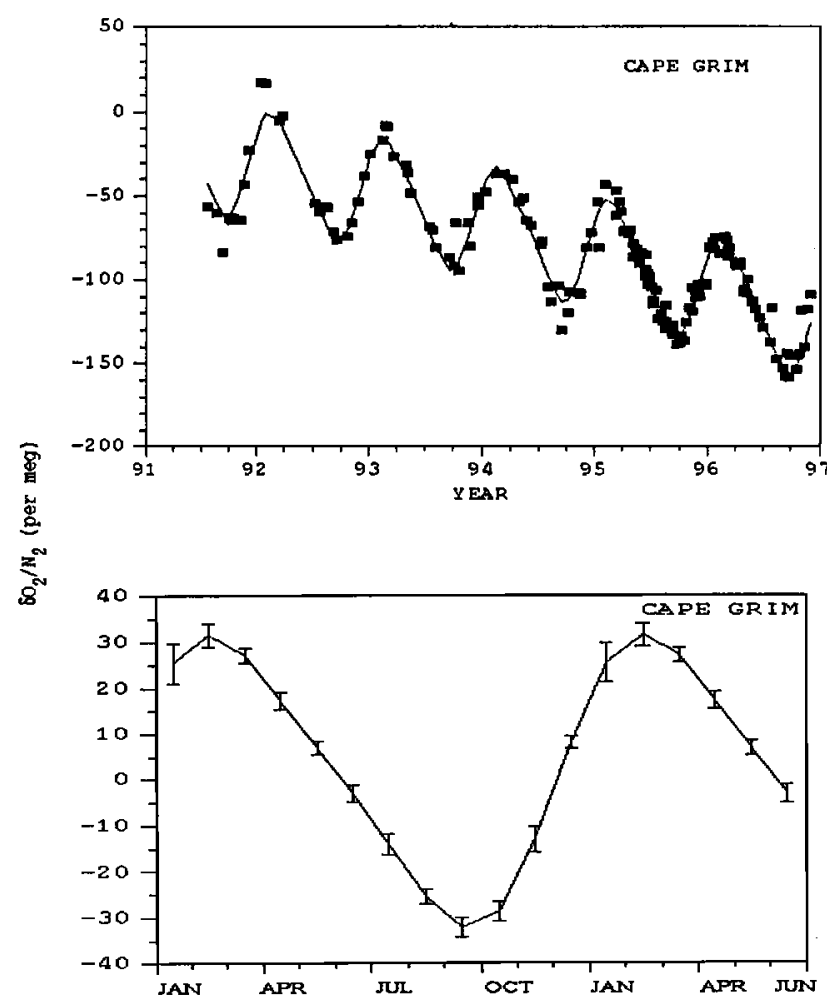

Figure 8. Steps to obtain the oceanic contribution of the signal in $\mathrm{O}_{2} / \mathrm{N}_{2}$ at Cape Grim. In step1, seasonal variations in $\mathrm{O}_{2} / \mathrm{N}_{2}$ fitted with a second-order polynomial using two harmonics [see Keeling and Shertz, 1992, Figure 1]. These data are then detrended following the procedure described by McIntosh et al. [1996]. Step 2 involves the oceanic contribution to atmospheric $8 \mathrm{O}_{2} / \mathrm{N}_{2}$ (see text). The $\mathrm{CO}_{2}$ flasks at Barrow, Cape Grim, and Baring Head were analyzed at the Climate Monitoring and Diagnostics Laboratory, National Oceanic and Atmospheric Administration. The $\mathrm{CO}_{2}$ samples at Mauna Loa and La Jolla were measured from the same flasks as $\mathrm{O}_{2} / \mathrm{N}_{2}(R$. Keeling, personal communication, 1996)

described by Thoning et al. [1989] and McIntosh et al. [1996]. In step 2, the seasonal variations are fitted with a second-order polynomial using two harmonics (see K-S, Figure 1). In step 3, the oceanic contribution to atmospheric $\delta \mathrm{O}_{2} / \mathrm{N}_{2}$ is derived from (2).

Strictly speaking, we are comparing data reflecting both ocean biology and thermal effects with a model driven by both ocean biology and thermal effects (Figure 9).

Our simple representation of the ocean by the globalized 1-D model, where biological activity is derived from the ocean color, captures reasonably well the amplitude and the phase of the seasonal variations observed at all five sites. In addition, the model predicts the asymmetric shape that is observed at Cape Grim and at Baring Head. The large $\mathrm{O}_{2} / \mathrm{N}_{2}$ increase that occurs at spring's end is due both to an increased production and to mixed layer stratification (see also Figure 2). The oxygen is rapidly outgased to the atmosphere only when a shallow mixed layer $(50 \mathrm{~m})$ is present. In early spring, when the mixed layer is deep (100 $\mathrm{m}$ or more), locally balanced remineralization occurs and oxygen outgasing is delayed by at least 1 month.

In contrast, the model fails to capture the slow drop in the $\mathrm{O}_{2} / \mathrm{N}_{2}$ ratio observed in the fall and winter seasons. This difference in the shape of the curve is not surprising since the 1-D model has a very crude ventilation of the main thermocline.

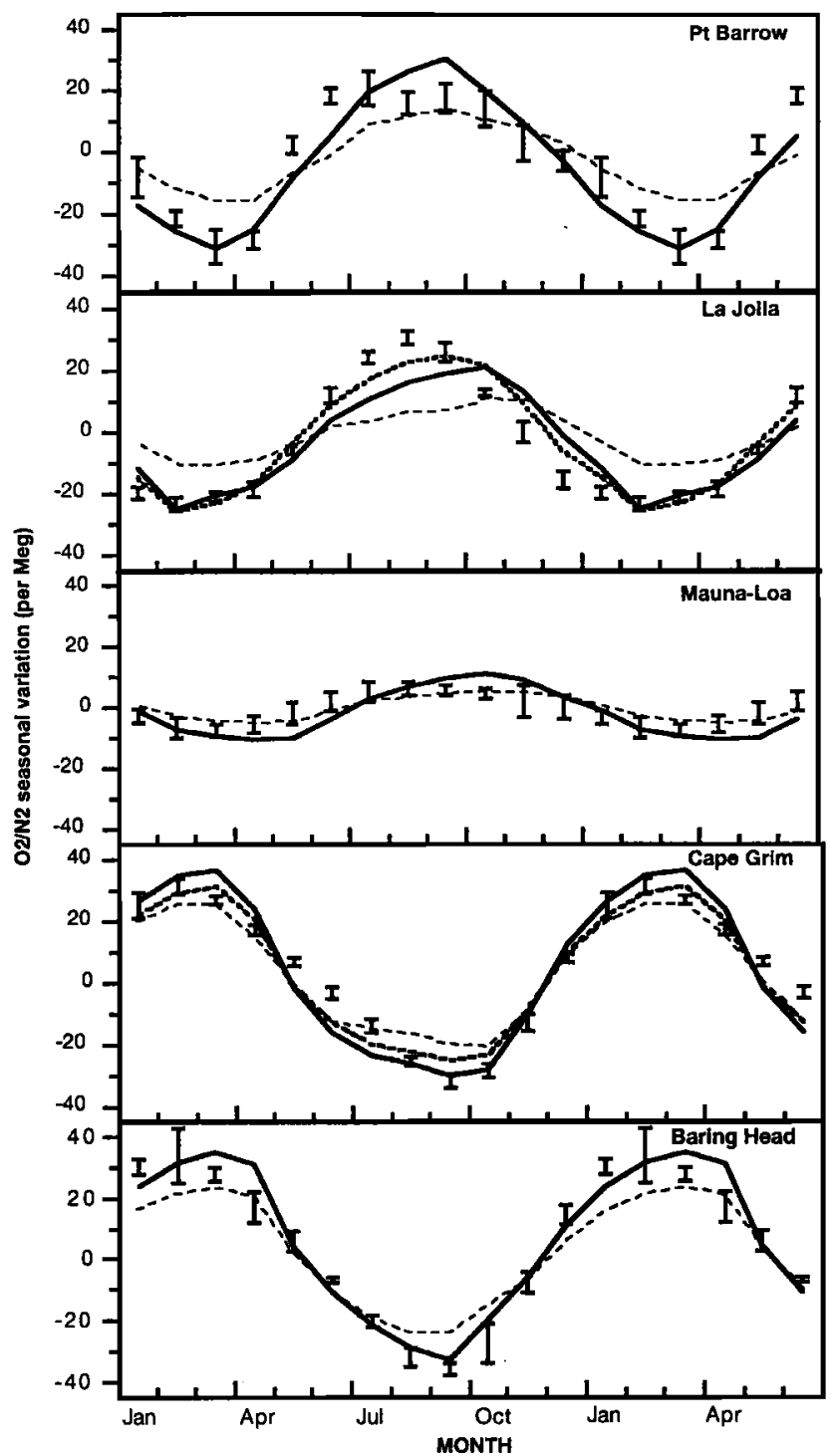

Figure 9. Relative variations in $\mathrm{O}_{2} / \mathrm{N}_{2}$ (per meg) at the five sites considered (Barrow, La Jolla, Mauna Loa, Cape Grim, and Baring Head). The oceanic component of the measurements from Bender et al [1996, 1998] at Barrow, Cape Grim, and Baring Head derived as described in text and Figure 8 are compared to model results (solid lines). The dashed lines at La Jolla and Cape Grim correspond to the nearest model oceanic grid box that corresponds to wind sector selection in $\mathrm{O}_{2} / \mathrm{N}_{2}$ or $\mathrm{CO}_{2}$ measurements (see text). The error bars represent the ratio of the standard deviation for detrended measurements from different years divided by the square root of the number of years of measurements minus 1. Measurements at La Jolla and Mauna Loa from R. Keeling (personal communication, 1996) are also included. 
Table 2. Percentage of the Contribution of Different Oceanic Processes to $\mathrm{O}_{2} / \mathrm{N}_{2}$ Seasonal Cycle

\begin{tabular}{c|ccc}
\hline & $\begin{array}{c}\text { Marine Biosphere } \\
\text { Locally Balanced Processes } \\
\text { (NEZP and Respiration) }\end{array}$ & $\begin{array}{c}\text { Nonlocally Balanced } \\
\text { Process, } \\
\text { Lateral Ventilation }\end{array}$ & $\begin{array}{c}\text { Oceanic Thermal } \\
\text { Ingasing and Outgasing }\end{array}$ \\
\hline $\begin{array}{c}\text { Point Barrow, } \\
71^{\circ} \mathrm{N}, 156^{\circ} \mathrm{W}\end{array}$ & 40 & 50 & 10 \\
$\begin{array}{c}\text { La Jolla, } \\
33^{\circ} \mathrm{N}, 117^{\circ} \mathrm{E}\end{array}$ & 40 & 48 & 12 \\
$\begin{array}{c}\text { Mauna Loa*, } \\
20^{\circ} \mathrm{N}, 156^{\circ} \mathrm{W}\end{array}$ & 36 & 52 & 12 \\
$\begin{array}{c}\text { Cape Grim, } \\
40^{\circ} \mathrm{S}, 144^{\circ} \mathrm{E}\end{array}$ & 55 & 29 & 16 \\
$\begin{array}{c}\text { Baring Head, } \\
41^{\circ} \mathrm{S}, 170^{\circ} \mathrm{E}\end{array}$ & 58 & 28 & 14 \\
$\begin{array}{c}\text { Mawson } \\
67^{\circ} \mathrm{S}, 63^{\circ} \mathrm{E}\end{array}$ & 53 & 32 & 15 \\
\hline
\end{tabular}

Here we used the definition of the seasonal mean contribution proposed by Kaminski et al. [1996] to derive the individual contributions of the marine processes. If the vector $V_{i}$ represents the 12 monthly components, and the overall seasonal cycle is represented by $\mathbf{V}_{t o t}$, the yearly mean contribution is then $\Sigma\left(V_{i} \cdot V_{t o t}\right) / \Sigma\left(V_{t o t} \cdot V_{t o t}\right)$.

NEZP is net $\mathrm{O}_{2}$ production in the euphotic zone.

* An annually constant production from $11^{\circ} \mathrm{S}$ to $11^{\circ} \mathrm{N}$ was imposed.

${ }^{\dagger}$ No data are yet available for this Antarctic coastal station.

At Barrow, the model predicts the phasing of the seasonal signal well, even though the predicted drop in $\mathrm{O}_{2} / \mathrm{N}_{2}$ is more rapid than the observed one. The amplitude of the seasonal cycle is slightly overestimated.

The site where the model has the most difficulty representing the seasonal signal is La Jolla. The rise in $\mathrm{O}_{2} / \mathrm{N}_{2}$ that accompanies the stratification of the mixed layer is clearly not as rapid and strong in the model. To quantify the influence of the land/ocean partition in the grid box where La Jolla is located, we examined the seasonal cycle of the neighboring grid boxes both to the west and to the north west of the La Jolla box. The differences in seasonal amplitudes of these different model boxes can explain half the discrepancy seen in Figure 9. This effect must be included owing to the systematic preselection of sample collections [see Ramonet and Monfray, 1996]. Part of the discrepancy we find at La Jolla could also be due to the fact that local upwelling and productivity are not captured in the model. We cannot rule out two other possible explanations for this discrepancy: first the NEZP of the north-eastern Pacific could be higher than we have estimated. Second, the modeled NMLP in this area could be too low owing to an excessively deep mixed layer or excessively shallow remineralization.
At Mauna Loa, the model overestimates the amplitude of the seasonal signal as it does at Barrow, while the rise in oxygen concentrations lags 1 month behind the observations. Part of this discrepancy could be due to overly vigorous vertical mixing in the TM2 model inducing a stronger seasonal signal at $3000 \mathrm{~m}$, the altitude of Mauna Loa Obervatory (MLO). The difficulty of capturing the phasing at Mauna Loa has been discussed by Keeling et al. [1998].

\subsection{Atmospheric $\mathrm{O}_{2} / \mathrm{N}_{2}$ and Net Oceanic Productivity}

As pointed out in section 5.2.1., four processes (solubility-driven fluxes, photosynthetic production, locally balanced consumption, and lateral ventilation of deep waters) contribute to the seasonality of $\mathrm{O}_{2} / \mathrm{N}_{2}$ in air.

We summarize in Table 2 the relative contributions, at the five sites (Barrow, La Jolla, Cape Grim, Mauna Loa and Baring Head), of locally balanced marine processes (production and respiration in the mixed layer or the seasonal thermocline), of lateral ventilation, and of the solubility effect. We can see from Table 2 that photosynthetic production and locally balanced consumption are the main oceanic components driving the 
$\mathrm{O}_{2} / \mathrm{N}_{2}$ amplitude at the southern stations, whereas lateral ventilation is the main component of the model driving seasonal variations at northern latitudes. This holds not only at Barrow (as shown in Figure 6) but also at midlatitude and low-latitude stations (La Jolla and Mauna Loa) via atmospheric transport. It is noteworthy that such behavior can also be found near the Antarctic coast (see, for example, Mawson in Table 2). Without $\mathrm{O}_{2} / \mathrm{N}_{2}$ measurements in the region, we cannot infer whether deep water ventilation is as important for the marine component of the oxygen seasonal signal as the model suggests.

In general terms, the model indicates that one third of the seasonal signal is due to deep water lateral ventilation in the midsouthern hemisphere while at least half of the marine signal is induced by lateral ventilation at northern latitudes. Locally balanced processes (production and respiration) account for $36 \%$ to $58 \%$ of the signal, while the effects of solubility changes are much less important (below $16 \%$ at all six sites).

Furthermore, as shown in Figure 8, large interannual variations in atmospheric $\mathrm{O}_{2} / \mathrm{N}_{2}$ occur in the real world. Measurements at Cape Grim and Baring Head show a seasonal amplitude of the marine component of $\mathrm{O}_{2} / \mathrm{N}_{2}$ of 84 per meg in 1991-1992. This is considerably larger than the amplitude of 53 per meg measured in 1993-1994. These year to year differences in the seasonal amplitude could be either due to biology (availability of nutrients, light, or temperature limitation) or to changes in the deepening and shoaling of the mixed layer induced by surface winds or buoyancy fluxes. Unfortunately, there is no information on either ocean color data or on the depth of the mixed layer for this period.

\section{Conclusions}

We have used a simple 1-D model of the oceanic water column forced by climatological archives of ocean color, cloudiness, surface wind speed, sea surface temperatures and density profiles, to derive the seasonal fields of air-sea $\mathrm{O}_{2}$ fluxes. These fluxes were dispersed using a 3-D atmospheric transport model to derive $\mathrm{O}_{2} / \mathrm{N}_{2}$ atmospheric variations and compare them with observations at five locations. Oxygen air-sea fluxes from the model described here account for a large part of the phase and amplitude of the $\mathrm{O}_{2} / \mathrm{N}_{2}$ seasonal variations at the five sites discussed (Cape Grim $\left(40^{\circ} \mathrm{S}\right)$, Baring Head $\left(41^{\circ} \mathrm{S}\right)$, Mauna-Loa $\left(20^{\circ} \mathrm{S}\right)$, La Jolla $\left(33^{\circ} \mathrm{N}\right)$, and Barrow $\left.\left(71^{\circ} \mathrm{N}\right)\right)$. These encouraging results were obtained despite numerous uncertainties in chlorophyll from ocean color, primary production, mixed layer depth, and mechanisms of gas exchange and remineralization. Remineralization is severely underconstrained because we assume a constant remineralization scheme based on NABE site data. If our estimation of the $f$ ratio, $(0.37$ at the base of the mixed layer) is overestimated, the satellite-derived production would then be underestimated. These uncertainties will have to be addressed using seasonal dissolved oxygen at different depths [Najjar and Keeling, 1997] before we can explain the observed interannual variations in $\mathrm{O}_{2} / \mathrm{N}_{2}$.

The mixed layer depth appears to play a significant role in controlling seasonal $\mathrm{O}_{2} / \mathrm{N}_{2}$ variations. In spring, the $\mathrm{O}_{2}$ outgasing is reduced by locally balanced consumption and delayed by limited gas exchange. In summer, part of $\mathrm{O}_{2}$ production is trapped below the mixed layer. In fall and winter, the increased depth of the mixed layer allows ventilation first to the subsurface, followed by intermediate and deep waters. Furthermore, the amplitude and phasing of the $\mathrm{O}_{2} / \mathrm{N}_{2}$ seasonal variations depend on the ventilation of both the seasonal thermocline and deep waters. Measurements of atmospheric $\mathrm{O}_{2} / \mathrm{N}_{2}$ in an area where deep convection occurs, such as south of the Antarctic Polar Frontal Zone, would be extremely valuable to estimate the importance of the lateral ventilation in redistributing the oxygen demand and its year to year variations. The inclusion of the oxygen and carbon cycles in a model that takes into account both mixed layer dynamics and 3-D advection will further constrain the biological activity.

A first step toward a prognostic approach has been made by Six and Maier-Reimer [1996], who embedded a simple plankton model in the 3-D oceanic model HAMOCC3. These authors found good agreement between the observed and simulated seasonal cycle at Cape Grim, especially during the ventilation period. However, the rapid degasing in spring occurred 2 months earlier, potentially linked to their crude representation of mixed layer dynamics.

In a related study, Keeling et al. [1998] examined the seasonal cycle of $\mathrm{O}_{2} / \mathrm{N}_{2}$ by prescribing the observed super/undersaturation of oxygen in surface waters. This diagnostic approach, complementary to the present work, also reproduces the measured seasonal cycle of $\mathrm{O}_{2} / \mathrm{N}_{2}$ in the northern hemisphere sites. For the southern ones, the poor coverage of oceanic oxygen measurements requires the use of a significant correction to remove the undersampling bias.

The observed $\mathrm{O}_{2} / \mathrm{N}_{2}$ values in the southern hemisphere allow us to make a crude estimate of the net production at latitudes that influence the austral sites. From $34^{\circ}$ to $49^{\circ} \mathrm{S}$, we estimate a net production of $4.3 \mathrm{~mol} \mathrm{C} \mathrm{m}^{-2} \mathrm{yr}^{-1}$. These values are noticeably larger than those inferred from ${ }^{14} \mathrm{C}$ incubations, as Bender et al. [1996] point out.

Finally, this study demonstrates that satellite data and hydrographic data are compatible with observed surface atmospheric oxygen data. However, a validation in midtroposphere is still needed. This requires a record of the seasonal variations of $\mathrm{O}_{2} / \mathrm{N}_{2}$ with altitude. A measurement program recently begun by $R$. Langenfeld and R. Francey (Commonwealth Scientific and Industrial Research Organisation, personal communication, 1996) opens the way for such study in the near future.

Acknowledgments. We are indebted to Michael Bender, JeanMichel Andre, and Katharina Six for useful discussions. This work was supported by a grant from the Commission of the European Community EV5V CT92-0120 and by the Programme National d'Etude de la Dynamique du Climat (PNEDC). We 
acknowledge computing support from the Commissariat à l'Energie Atomique (CEA). This is LSCE report 48.

\section{References}

Antoine, D., and A. Morel, Oceanic primary production, 1, Adaptation of a spectral light-photosynthesis model in view of application to satellite chlorophyll observations, Global Biogeochem. Cycles, 10, 43-55., 1996.

Antoine, D., J. M. André, and A. Morel, Oceanic primary production, 2, Estimation of global scale from satellite (coastal zone color scanner) chlorophyll, Global Biogeochem. Cycles, 10, 57-69, 1996.

Bender, M., H. Ducklow, J. Kiddon, J. Marra, and J. Martin, The carbon balance during the 1989 spring bloom in the North Atlantic Ocean, Deep Sea Res., Part A, 39, 1707-1725, 1992.

Bender, M., T. Ellis, P. Tans, R. Francey, and D. Lowe, Variability in the $\mathrm{O}_{2} / \mathrm{N}_{2}$ ratio of the southern hemisphere air, 1991-1994: Implications for the carbon cycle, Global Biogeochem. Cycles, 10, 9-21, 1996.

Bender, M., M. Battle, and R. Keeling, The $\mathrm{O}_{2}$ balance of the atmosphere: A tool for studying the fate of fossil fuel $\mathrm{CO}_{2}$, Annu. Rev. Energy Environ. Sci., in press, 1998.

Bengsston, L., M. Kanamitsu, P. Kallberg, and S. Uppala, FGGE 4-dimensional data assimilation at ECMWF, Bull. Am. Meteorol. Soc., 63, 29-43, 1982.

Broecker, W., and T.-H. Peng, Tracers in the Sea, LamontDoherty Geol. Lab., Palisades, N. Y., 1982.

Esaias, W. E., G. C. Feldman, C. R. McClain, and J. A. Elrod, Monthly satellite-derived phytoplankton pigment distribution for the North Atlantic Ocean Basin, Eos Trans. AGU, 67, 1986.

Feldman, G. C. et al., Ocean color: Availability of the global data set, Eos Trans. $A G U, 70,634-635,640-641,1989$.

Heimann, M., The global atmospheric tracer model TM2, Rep. 10, Max-Planck-Inst. fur Meteorol., Hamburg, Germany, 1995.

Heimann M., and C. D. Keeling, A three-dimensional model of atmospheric $\mathrm{CO}_{2}$ transport based on observed winds, 2, model description and simulation of tracer experiments, in Aspects of Climate Variability in the Pacific and the Western Americas, Geophys. Monogr. Ser., vol 55, edited by D.H. Peterson, pp. 237-275, AGU, Washington D.C., 1989.

Jacob, D. J., et al., Evaluation and intercomparison of global atmospheric - transport models using ${ }^{222} \mathrm{Rn}$ and other shortlived tracers, J. Geophys. Res., 102, 5953-5970, 1997.

Jenkins, W. and J. Goldman, Seasonal oxygen cycling and production in the Sargasso Sea, J. Mar. Res., 43, 465-491, 1985.

Kaminski, T., R. Giering, and M. Heimann, Sensitivity of the seasonal cycle of $\mathrm{CO}_{2}$ at remote monitoring stations with respect to seasonal surface exchange fluxes determined with the adjoint of an atmospheric transport model, Phys. Chem. Earth, 21(5-6), 457-462, 1996.

Keeling R. F., and S. R. Shertz, Seasonal and interannual variations in atmospheric oxygen and implications for the global carbon cycle, Nature, 358, 723-727, 1992.

Keeling, R., R. Najjar, M. Bender, and P. Tans, What atmospheric oxygen measurements can tell us about the global carbon cycle, Global Biogeochem. Cycles, 7, 37-67, 1993.

Keeling, R., B. Stephens, R. Najjar, S. Doney, D. Archer, and M. Heimann, Seasonal variations in atmospheric $\mathrm{O}_{2} / \mathrm{N}_{2}$ ratio in relation to the kinetics of air-sea gas exchange, Global Biogeochem. Cycles, 12, 141-163, 1998.
Laws, E. A., Photosynthetic quotients, new production, net community production in the open ocean, Deep Sea Res., 38, Part A, 143-167, 1991.

Levitus, S., Climatological atlas of the world ocean, NOAA Prof. Pap. 13, 173pp., U.S. Govt. Print. Off., Washington D.C., 1982.Liss, P. S. and L. Merlivat, Air-sea exchange rates: introduction and synthesis, in The Role of Gas in Geochemical Cycling, edited by P. Buat M'enart, pp. 113127, D. Reidel, Norwell, Mass., 1986.

Heimann M., and P. Monfray and G. Polian, Modeling the longrange transport of ${ }^{222} \mathrm{Rn}$ to the subantarctic and antarctic areas, Tellus, Ser. B, 42B, 83-99, 1990.

Machta L., and E. Hughes, Atmospheric oxygen in 1967 and 1970, Science, 168, 1582-1584., 1970.

Mahowald, N. M., P. J. Rasch, and R. G. Prinn, Cumulus parameterizations in chemical transport models, J. Geophys. Res., 100, 26173-27190, 1995.

Martin, J. H., G. A. Knauer, D. M. Karl, and W. W. Broenkow, VERTEX: Carbon cycling in the northeast pacific, Deep Sea Res., Part A, 34, 267-285, 1987.

McIntosh, C. M., E. J. Dugokencky, P. M. Land, and K. A. Masarie, Atmospheric $\mathrm{CH}_{4}$ seasonal cycles and latitude gradient from the NOAA CMDL cooperative air sampling network, Tech. Memo. ERL CMDL-11, Natl. Oceanic and Atmos. Admin., Silver Spring, Md., 1996.

Morel, A., Light and marine photosynthesis: A spectral model with geochemical and climatological implications, Prog. Oceanogr., 26, 617-649, 1991.

Morel A., and J. F. Berthon, Surface pigments, algal biomass profiles and potential production in the euphotic layers: Relationships re-investigated in view of remote sensing applications, Limnol. Oceanogr., 34, 1545-1562, 1989.

Najjar R., and R. Keeling, Analysis of the mean annual cycle of the dissolved oxygen anomaly in the world ocean, J. Mar. Res., 55, 117-151, 1997.

Peng, T. -H., T. Takahashi, W. S. Broecker, and J. Olafsson, Seasonal variability of carbon dioxide, nutrients and oxygen in the northem North Atlantic surface water: Observations and a model, Tellus, Ser. B, 39B, 439-458, 1987.

Ramonet, M., Modélisation du transport atmosphérique du dioxyde de carbone dans l'h'emisphère sud , Ph.D. dissertation, Univ. de Paris VII, Paris, 1994.

Ramonet, M. and P. Monfray, $\mathrm{CO} 2$ baseline concept in 3-d atmospheric transport models, Tellus, Ser. B, 48B, 502-520, 1996.

Ramonet, M., J. L. Roulley, P. Bousquet, and P. Monfray, Radon222 measurements during the TROPOZ II campaign and comparison with a global atmospheric transport model, $J$. Atmos. Chem., 23, 107-136, 1996.

Rossow, W., Y. Zhang, P.-J. Lu, and A. Walker, International satellite cloud climatology project (ISCCP) documentation of cloud data, Publ. WMO/TD-No.266, 78 pp., World Meteorol. Organ., Geneva., 1988.

Russel, G. L. and J. A. Lerner, A new finite-differencing scheme for the tracer transport equation, J. Appl. Meteor., 20, 14831498, 1981.Schulenberger, E. and J. Reid, The pacific shallow oxygen maximum, deep chlorophyll maximum, and primary productivity reconsidered, Deep Sea Res., 28, 901-919, 1981.

Severinghaus, J., P., Studies of the Terrestrial $\mathrm{O} 2$ and Carbon Cycles in Sand Dune Gases and in Biosphere 2, Ph.D. dissertation, Columbia Univ., New York, 1995.

Six K.D., and E. Maier-Reimer, Effects of plankton dynamics on seasonal carbon fluxes in an ocean general circulation model, Global Biogeochem. Cycles, 10, 559-583, 1996. 
Sullivan, C. W., K. R. Arrigo, C. R. McCain, J. C. Comiso, and J. Firestone, Distributions of phytoplankton blooms in the Southern Ocean, Science, 262, 1832-1837, 1993.

Thoning, K., P. Tans, and W. Komhyr, Atmospheric carbon dioxide at Mauna Loa Observatory, 2, Analysis of the NOAA GMCC data, 1974-1985, J. Geophys. Res., 94, 8549-8565, 1989.

Tiedtke, M., A comprehensive mass flux scheme for cumulus parameterization in large-scale models, Mon. Weather Rev., 17, 1779-1800, 1989.

Walsh, J., A data set on northern hemisphere sea ice extent, 19531976, Glaciological data, World Data Cent. for Glaciol. (Snow and Ice), Boulder, Colo., 1978.

Weiss, R. F., The solubility of nitrogen, oxygen and argon in water and seawater, Deep Sea Res., 17, 721-735, 1970.

Williams, P. J. L., On the definition of plankton production terms, ICES Mar. Sci. Symp., 197, 9-19, 1993.

Yoder, A., C. McClain, G. Feldman, and W. Esaias, Annual cycles of phytoplankton chlorophyll concentrations in the global ocean: A satellite view, Global Biogeochem. Cycles, 7, 181193, 1993.

Zwally, H. J., J./Comiso, C. Parkinson, W. Campbell, F. Carsey, and P. Gloerson, Antarctic Sea Ice, 1973-1976: Satellite Passive Microwave Observations, NASA, 1983.

Y. Balkanski and P. Monfray, Laboratoire des Sciences du Climat et de l'Environnement, CEA-DSM, CE Saclay, l'Orme des Merisiers, F-91191 Gif-sur-Yvette, France. (e-mail:

ybalkanski@cea.fr; monfray@obelix.saclay.cea.fr.)

M. Battle' Department of Geosciences, Princeton University, Princeton, NJ 08544.

M. Heimann,' Max-Planck-Institut fuer Biogeochemie

Postfach 100164, D-07745 Jena, Germany

(Received November 3, 1997; revised April 28, 1998;

accepted July 10, 1998.) 